\title{
FROM NUCLEAR NON-PROLIFERATION TREATY (NPT) TO THE TREATY ON PROHIBITION OF NUCLEAR WEAPONS (TPNW): SHIFTING PARADIGM AND ITS IMPLEMENTATION'S OBSTACLES
}

\author{
Nahda Anisa Rahma*
}

\begin{abstract}
Since its enforcement in 1970, it is evident that the negotiations process towards nuclear disarmament under the Nuclear Non-Proliferation Treaty (NPT) has encountered stagnation. This fact led to the inception of the Treaty on the Prohibition of nuclear weapons (TPNW) which possesses a distinct characteristic of NPT. TPNW utilizes a more digestible humanitarian approach, which emphasized the catastrophic impacts of possessing nuclear weapons, rather than the complex statesecurity approach. This study aims to primarily provide an in-depth understanding regarding the shifting regime from NPT to TPNW and nuclear disarmament in general. The author conducts the research by using the literature research method, and thereafter analyzes the relevance and employs the arguments contained in the literature critically. The research shows that the traditional paradigm in NPT is insufficient to achieve the goal of complete nuclear disarmament, as it only focuses on the interest and security of the states. Thus delegitimizing the existence of public participation, which is important to put pressure to mobilize the political will of the state. This article also shows the possible obstacles that TPNW might face during its upcoming implementation.
\end{abstract}

Keywords: Nuclear weapons, Nuclear Ban Treaty, Non-Proliferation Treaty, humanitarian approach.

Student at Department of International Law Universitas Gadjah Mada. Email: nahda.a.r@mail.ugm.ac.id. 


\title{
DARI PERJANJIAN PENGAWALAN SENJATA NUKLEAR (NPT) KEPADA PERJANJIAN PENGHARAMAN SENJATA NUKLEAR (TPNW): ANJAKAN PARADIGMA DAN HALANGAN PERLAKSANAAN
}

\begin{abstract}
ABSTRAK
Sejak pelaksanaannya pada 1970, adalah terbukti bahawa proses rundingan terhadap perlucutan senjata nuklear dalam Perjanjian Pengawalan Senjata Nuklear (NPT) menemui jalan buntu. Fakta ini telah membawa kepada permulaan kepada Perjanjian Pengharaman Senjata Nuklear (TPNW) yang mempunyai ciri-ciri yang tersendiri berbanding NPT. TPNW menggunakan pendekatan kemanusian yang lebih mudah dihadam, dengan menekankan kesan malapetaka memiliki senjata nuklear, berbanding pendekatan keselamatan negara yang rumit. Matlamat utama makalah ini adalah memberikan pemahaman yang mendalam berkaitan dengan perubahan rejim dari NPT kepada TPNW dan gencatan nuklear secara umum. Penulis telah membuat kajian mengunakan kaedah penyelidikan literatur , dan menganalisa kaitan dan secara kritikal menggunakan hujah di dalam literatur. Makalah ini menunjukan bahawa paradigma tradisional dalam NPT adalah tidak mencukupi untuk mencapai matlamat dalam menyempurnakan gencatan nuklear, kerana ianya hanya memfokuskan kepada kepentingan dan keselamatan negara. Dengan demikian ia melegitimasi kewujudan penyertaan awam yang penting untuk memberi tekanan kepada menggerakkan kehendak politik negara. Makalah ini juga menunjukkan kemungkinan halangan-halangan yang mungkin TPNW hadapi semasa pelaksanaannya nanti.
\end{abstract}

Kata kunci: Senjata nuklear, Perjanjian Pengharaman Nuklear, Perjanjian Pengawaln Senjata, pendekatan kemanusiaan.

\section{INTRODUCTION}

The discourse surrounding the utilization of nuclear weapons has been ongoing for decades. Since the 1945 nuclear test on the desert of New Mexico, the impacts of nuclear weapons, which were described as "unprecedented, magnificent, beautiful, stupendous, and terrifying", 
had frightened the international society. ${ }^{1}$ Not long after, the overwhelming impacts of nuclear weapons were proven through the bombing of Hiroshima and Nagasaki, yielding to the casualties of approximately two hundreds thousands people. ${ }^{2}$ The trauma inflicted by the unimaginable dangers and destruction of a nuclear calamity has been translated into the desire to ban the proliferation of nuclear weapons. Not to mention that the occurrences of these dangers could lay out not only by a deliberate intentional act but even more dreadful, the possibilities of an accident, miscalculation, human or mechanical failure during the operationalization of nuclear weapons. The willingness to dodge the devastation caused by nuclear weapons has proven to be the most powerful deterrence to the development of nuclear weapons. ${ }^{3}$

However, it should be noted that there are also several incentives for having nuclear weapons in the states' consideration. To this date, there are only 9 (nine) countries that possess nuclear weapons; the United States, United Kingdom, Russia, France, China, India, Pakistan, Israel, and North Korea. Former states which owned nuclear weapons are the former Soviet Republics which are Belarus, Kazakhstan, and Ukraine, whose weapons were repatriated to Russia also South Africa whose voluntarily dismantled their nuclear weapons in the process of the development. ${ }^{4}$ William Epstein argues the incentives of going nuclear outweigh the disincentives ${ }^{5}$, which he further elaborates by stating that for states with precarious security matters, possessing nuclear weapons will bring tremendous military advantages such as maintaining superiority and achieving a greater degree of military independence. Even for states without acute security problems, it will

1 Elizabeth Minor, "Changing the Discourse on Nuclear Weapons: The Humanitarian Initiative," International Review of the Red Cross 97 (2016): 711.

2 Atomic Archive, The Atomic Bombings of Hiroshima and Nagasaki, https://www.atomicarchive.com/resources/documents/med/med_chp10.h tml (accessed on 4 December 2020).

3 William Epstein, "Why States Go - And Don't Go - Nuclear," The Annals of the American Academy of Political and Social Science 430, no. 1 (1977): 17.

4 Paul R Viotto, Arms Control and Global Security: A Document Guide (Santa Barbara: ABC-CLIO, 2010), 312.

5 Epstein, "Why States Go - And Don’t Go - Nuclear," 18. 
still bring benefits like uplifting their status and political prestige in the eyes of the international society.

The aforementioned incentives, nonetheless, were not able to devalue the scars of the international society caused by the horrors of nuclear weapons calamities. The fear by the global community of the widespread of nuclear weapons also combined with the political interests of nuclear states resulted in the 1968 Treaty on the NonProliferation of Nuclear Weapons (NPT). ${ }^{6}$ The inception of NPT itself was very interesting. Subsequent to the Cold War, the two most powerful states at that time but also enemies for each other, the United States and the Soviet Union, collaborated in initiating the drafting of the NPT. During the Eighteen Nation Disarmament Committee talks, the primary approach of the NPT was to protect state security. ${ }^{7}$ Evaluating it from this perspective, it was apparent why many states sought to avoid the proliferation of nuclear weapons. For example, the interest of the Soviet Union in the matter of proliferation was focused upon the dangers of a nuclear role for West Germany. ${ }^{8}$ In general, there were perceived common interests, from the nuclear powers and the non-nuclear countries that has no likelihood of having nuclear weapons in the very first place (never-nuclear), to hamper the major industrial states (e.g. Japan and West Germany) and Third World countries (e.g. India, Brazil) from possessing nuclear weapons ${ }^{9}$.

The state-security approach prevailed until 2010, where from onwards, the emergence of intolerable humanitarian consequences of nuclear weapons has been the subject of international discussion..$^{10}$ It has led to the dominance of the humanitarian approach in the disarmament discourse, where it emphasizes the protection of individuals and humanitarian impacts rendered by a nuclear explosion,

6 Treaty on the Non-Proliferation of Nuclear Weapons (NPT), 729 UNTS 10485, 1 July 1968 (entered into force 5 March 1970).

7 Bonnie Docherty, “A 'Light for All Humanity': The Treaty on the Prohibition of Nuclear Weapons and the Progress of Humanitarian Disarmament," Global Change, Peace and Security 30, no. 2 (2018): 8, https://doi.org/10.1080/14781158.2018.1472075.

8 James E Dougherty et al., "The Non-Proliferation Treaty" 25, no. 1 (1966): 15.

9 Epstein, "Why States Go - And Don't Go - Nuclear," 17.

10 Minor, "Changing the Discourse on Nuclear Weapons: The Humanitarian Initiative," 711. 
whether it is intentional or accidental, rather than the interest of states ${ }^{11}$. The budding of humanitarian approach was also the reason behind the initiation of a treaty that substantially aims to achieve a world without nuclear.

The Treaty on the Prohibition of Nuclear Weapons (henceforth referred to as "TPNW" or "Treaty") was adopted on July 7, 2017, as a follow-up from General Assembly Resolution A/RES/71/258 on December 23rd, 2016. 122 (one hundred and twenty-two) states voted for the global ban of nuclear weapons, with 1 (one) country, Netherlands, who voted against, and 1 (one) country, Singapore, who abstained from voting. ${ }^{12}$ No nuclear weapons states that are parties of the NPT or other states possessing nuclear weapons participated in the making or discussion process of the Treaty. The Treaty entered into force on January 22nd, 2021, after Honduras as the 50th country deposited its ratification instrument to the Secretary-General of the United Nations fulfilled the Treaty's entry into force provisions. It is noticeable that TPNW, to some extent, has deviated from the nuclearrelated treaty, namely NPT. This can be seen in the preamble of the Treaty where it mentioned the concerns regarding "the catastrophic humanitarian consequences" and Article 6 in regards to victim assistance and environmental remediation.

As both NPT and TPNW ruled the same object but with a different approach, this article is interested in examining the shifting paradigm of these two treaties and identifying the possible obstacles that TPNW may face concerning its implementation. The primary objective of this research is to provide a more in-depth understanding of the shifting regime of nuclear treaties, the emergence of TPNW, and nuclear disarmament in general. The method of this research is analytical, by reviewing the existing literature, found in primary sources such as the Treaty and secondary sources such as journals, books, etc.

This research has carried out preliminary observations of several published articles on the topic. In general, most of the approaches taken

\footnotetext{
11 Minor, 712.

12 UN Conference Adopts Treaty Banning Nuclear Weapons, UN News Centre, 7 July 2017, https://news.un.org/en/story/2017/07/561122-unconference-adopts-treaty-banning-nuclear-weapons (accessed on 25 November 2020).
} 
by the majority of published articles apply a more narrow or broader perspective than this Article. The aforementioned articles to some extent overlap with this article, but there are still differences that will mirror the overall differences of past research and the current research. First, John Borrie ${ }^{13}$ published an article titled "Obstacles to understanding the emergence and significance of the treaty on the prohibition of nuclear weapons" in 2018 which solely focuses on the connection between the framing in regards with the stigma surrounding, the emergence of such discourses and the subsequent negotiation process of TPNW. Though similar, Borrie's article differs from this article because this research does not exclusively focus on the emergence process of the Treaty, but also analyzes the tangible implementation of the Treaty. Thus, this article offers a wider perspective.

Second, the article by Tom Sauer" titled "The potential stigmatizing effect of the Treaty on the Prohibition of Nuclear Weapons" attempts to decipher the extent of the process of treaty stigmatization which might take place by elaborating on the concepts of stigma and stigmatization, matching those concepts with nuclear weapons, and humanitarian initiative behind the momentum of TPNW. Lastly, Sauer finalized his article by conclusively comparing the different stigma management approaches. This article's approach is narrow as it particularly focuses on the stigmatization surrounding TPNW, meanwhile, it approaches the topic in a more extensive perspective by delineating the changing paradigm from state security's approach in NPT to the humanitarian approach in TPNW, as well as the potential obstacle in implementing the treaty.

Last but not least, the article by Tamara Patton" ${ }^{15}$ titled "Fit for Purpose: An evolutionary strategy for the implementation and

13 John Borrie, Michael Spies, and Wilfred Wan, "Obstacles to Understanding the Emergence and Significance of the Treaty on the Prohibition of Nuclear Weapons," Global Change, Peace and Security 30, no. 2 (2018): 95-119, https://doi.org/10.1080/14781158.2018.1467394.

14 Tom Sauer and Mathias Reveraert, "The Potential Stigmatizing Effect of the Treaty on the Prohibition of Nuclear Weapons," Nonproliferation Review 25, no. 5-6 (2018): https://doi.org/10.1080/10736700.2018.1548097.

15 Tamara Patton, Sébastien Philippe, and Zia Mian, "Fit for Purpose: An Evolutionary Strategy for the Implementation and Verification of the 
verification of the Treaty on the Prohibition of Nuclear Weapons", assesses the hindrance that will occur when TPNW is enacted, which has a lot of similarities with the Author's research. However, the primary focus of Patton's article centralizes on the urgency to establish a competent institution that can enforce the provisions contained in the Treaty. Patton's article is still distinguishable from this Article since this Article will offer more general hindrance or obstacles in implementing the Treaty, by covering the changing pattern of paradigm in approaching the issue of nuclear weapons, not only specifying in the establishment of a competent institution.

\section{DISCOURSE ON THE LEGALITY OF NUCLEAR WEAPONS}

As mentioned above, there has been a very heated, complex, comprehensive, and endless discourse surrounding nuclear weapons in international society for decades. The discourse regarding the legality of the threat or use of nuclear weapons is important to be elucidated in the onset to understand the impediment and complexities surrounding nuclear weapons and/or disarmament, particularly the principle of nuclear deterrence and humanitarian paradigm. The article will briefly explain the discourse by analysing the basis of arguments utilized by two courts in each case regarding nuclear weapons.

The first decision that gives a distinct point of view is the Shimoda case which was heard by the District Court of Tokyo on December 7, 1963. ${ }^{16}$ This is a legal action by five individuals in May 1955 against the Japanese Government to redress harm, damage, and injuries as a result of the Hiroshima and Nagasaki atomic bombings in 1945. One of the reasons why this case is worthy of further analysis is because this is the first judicial decision that assesses the legality of nuclear weapons with positive international laws. Until then, there was

Treaty on the Prohibition of Nuclear Weapons," Journal for Peace and Nuclear Disarmament 2, no. 2 (2019): 387-409, https://doi.org/10.1080/25751654.2019.1666699.

16 The verdict was translated by ICRC. See: Shimoda case (Compensation claim against Japan brought by the residents of Hiroshmina \& Nagasaki), Tokyo District Court, 7 December 1963. Available in https://www.icrc.org/applic/ihl/ihl-

nat.nsf/0/aa559087dbcf1af5c1256a1c0029f14d (hereinafter, Shimoda Judgment) 
no customary law that explicitly banned the use of nuclear bombs as a newly emerged weapon. The discussion revolved roughly around two issues; the applicability of international law to the use of new weapons when there is no explicit expression to prohibit the use of such weapons, and second, on the illegality of atomic bombings based on principles of the laws of war.

The plaintiffs of the Shimoda case began their arguments by presenting an emotional and detailed description of the consequences of the atomic attacks upon the cities of Hiroshima and Nagasaki. ${ }^{17}$ They stated that, for instance, "people in rags of hanging skin wandered about and lamented aloud among dead bodies. It was an extremely sad sight beyond the description of a burning hell and all imagination of anything heretofore known in human history". ${ }^{18}$ The court was also shocked by the facts given in the proceedings which proved that atomic bombs created the unprecedented effect with highly destructive force. Several grotesque depictions of the unnecessary sufferings caused by nuclear weapons incited the humanitarian nuance in the case, in which it violated permissible limits in warfare.

Moreover, the decision unravels the issue of the position of international law in permitting the utilization of weapons that are not explicitly prohibited. It must be noted that the court only attempted to answer the legality of the use of nuclear weapons in the context of Hiroshima and Nagasaki. ${ }^{19}$ The court applied several interpretations and analogies of pre-nuclear international law of war to address the issues posed. The court explained:

It can naturally be assumed that the use of a new weapon is legal as long as international law does not prohibit it. However, the prohibition in this context is to be understood to include not only the case where there is an express rule of direct prohibition, but also the case where the prohibition can be implied de plano from the interpretation and application by analogy of existing rules of international law. ${ }^{20}$

17 Richard A Falk, "The Shimoda Case: A Legal Appraisal of the Atomic Attacks Upon Hiroshima and Nagasaki," The American Journal of International Law 59, no. 4 (1965): 761.

18 Falk, 761.

19 Shimoda Judgment, p. 629.

20 Shimoda Judgment, p. 628. 
The court then decided the issue by finding relevance between existing rules concerning hostile acts and the facts of the case. The court stated that there is a differentiation of rules applied for "defended city" and "undefended city" in regards to bombardment by land and naval forces. Furthermore, in the context of aerial bombardment as regulated under the Draft Rules of Air Warfare, the court found that:

It can therefore be said that the prohibition of indiscriminate aerial bombardment of an undefended city and the principle of military objectives contained therein are rules of customary international law in view of the fact that these are also found in common in the rules of land and sea warfare. ${ }^{21}$

It was not disputed that Hiroshima and Nagasaki are categorized as "undefended cities" at the point of the attack. Thus, the court found it relevant to equate the rules to the case, by deciding that:

...In these circumstances, it is proper to conclude that the aerial bombardment with an atomic bomb of both Hiroshima and Nagasaki was an illegal act of hostilities under international law as it existed at that time, as an indiscriminate bombardment of undefended cities. This is so since aerial bombardment with an atomic bomb, even if its target is confined to military objectives, brings about the same result as a blind aerial bombardment with an atomic bomb, even if its target is confined to military objectives, brings about the same result as a blind aerial bombardment because of the tremendous setructive power of the bomb. ${ }^{22}$

Furthermore, the court invoked Article XXIII (e) of the Hague Regulations Respecting the Laws and Customs of War on Land which prohibits the use of weapons that cause unnecessary suffering. The court proceeded to highlight the casualties of the atomic bombings in Hiroshima and Nagasaki and stated that "the pain brought by the atomic bombs is severer than that from poison and poison-gas, and we can say that the act of dropping such a cruel bomb is contrary to the fundamental principle of the laws of war which prohibits the causing of unnecessary suffering." ${ }^{23}$ The recognition by the court on the level of cruelty and inhumane nuclear weapons possess endows the judgment with substantial importance. Even though it is unlikely that this judgment will influence the military policy in nuclear states,

21 Shimoda Judgment, p. 631.

22 Shimoda Judgment, p. 632

23 Shimoda Judgment, p. 634. 
nonetheless Shimoda case might be the start of an eye-opening climate of opinion in regards to the utilization of nuclear weapons.

Years later, the issue in the Shimoda case still prevails as seen in the International Court of Justice (ICJ)'s Advisory Opinion in 1996 concerning the legality of a threat or use of nuclear weapons. By a letter dated 19 December 1994, filed in the Registry on 6 January 1995, Secretary-General of the UN corresponded with the Registrar in regards to the decision of the General Assembly to submit a question to the Court as follows: "Is the threat or use of nuclear weapons in any circumstance permitted under international law?" Though controversial, the Court still proceeded to give its advisory opinion as it found relevance between the question put to the Court and the concerns of the General Assembly, specifically related to the threat or use of force in international relations, the disarmament process, and the progressive development of international law. ${ }^{24}$

The Court, similar to Shimoda case, noted the characteristics of nuclear weapons, which can destroy, cause untold human suffering, and cause damage to future generations, and should first be recognized to correctly apply the relevant laws. ${ }^{25}$ Addressing the question of the legality or illegality of assistance on nuclear weapons in the light of Article 2 paragraph 4 UN Charter, the Court found that the prohibition of the use of force is to be considered with another relevant provision of the Charter, such as Article 51 which recognizes the self-defence right in an armed attack, and Article 42 whereby military enforcement measures might be taken by the Security Council in conformity with the provisions under Chapter VII of the Charter. The Court further stated that:

...In order to be effective, the policy of deterrence, by which those States possessing or under the umbrella of nuclear weapons seek to discourage military aggression by demonstrating that it will serve no purpose, necessitates that the intention to use nuclear weapons be credible. Whether this is a "threat" contrary to Article 2, paragraph 4, depends upon whether the particular use of force envisaged would be directed against the territorial integrity or political independence of a State, or against the Purposes of the

24 Legality of the Threat or Use of Nuclear Weapons, Advisory Opinion, [1996] ICJ Reports (hereinafter, “The Nuclear Advisory Opinion"), para. $10-18$

25 The Nuclear Advisory Opinion, para. 35-36. 
United Nations, or whether, in the event that it were intended as a means of defence, it would necessarily violate the principles of necessity and proportionality. In any of these circumstances the use of force, and the threat to use it, would be unlawful under the law of the Charter. ${ }^{26}$

In analyzing the matter of whether the non-utilization of nuclear weapons since 1945 has been crystallized into a newly established custom, the Court contended that this was "merely because circumstances that might justify their use have fortunately not arisen". ${ }^{27}$ The Court further elaborates by acknowledging the division of views among the members of the international community on the matter of whether non-recourse to nuclear weapons over the past 50 years constitutes the expression of an opinio juris, in which the Court concluded by stating that It cannot find the existence of such an opinio juris. $^{28}$

Ultimately, by an evenly split number of votes on the matter of "policy of deterrence" with seven votes to seven, with the casting vote of the President, the Court states that:

It follows from the above-mentioned requirements that the threat or use of nuclear weapons would generally be contrary to the rules of international law applicable in armed conflict, and in particular the principles and rules of humanitarian law;

However, in view of the current state of international law, and the elements of fact at its disposal, the Court cannot conclude definitively whether the threat or use of nuclear weapons would be lawful or unlawful in an extreme circumstance of self-defence, in which the very survival of a State would be at stake. ${ }^{29}$ ",

Nevertheless, the aforementioned "evenly-split" decision was not as disputable within the Court as it may seem. ${ }^{30}$ Among the seven judges who voted against the decision, only 3 (three) judges had

26 The Nuclear Advisory Opinion, para. 48.

27 The Nuclear Advisory Opinion, para 66.

28 The Nuclear Advisory Opinion, para 67.

29 The Nuclear Advisory Opinion, para. 105.

30 Dieter Fleck, "The Treaty on the Prohibition of Nuclear Weapons: Challenges for International Law and Security," in Nuclear NonProliferation in International Law - Volume IV, ed. Jonathan L Blackbranch and Dieter Fleck (TMC Asser Press, 2019), 400. 
expressed an actual statement or constructed arguments to corroborate the prohibition of the threat or use of nuclear weapons even in extreme circumstances. First, Judge Weeramantry explicitly contends that in any circumstances, the threat or use of nuclear weapons is illegal as it is incompatible with the fundamental principle of international law. He further stated that it contradicts the fundamental principle of the dignity and worth of the human person on which all law depends and endangers the human environment in a manner that threatens the entirety of life on the planet. ${ }^{31}$ Second, Judge Shahabuddeen's dissenting opinion stated that there was a 'sufficient legal and factual basis on which the Court could have proceeded to answer the General Assembly's question', which also constructed arguments supporting a prohibition even in extreme cases. ${ }^{32}$

Third, Judge Koroma in his dissenting opinion, stated that he is principally against the Court's finding on the latter paragraph, based on the arguments that the deployment of nuclear weapons "would not only result in the violation of the territorial integrity of non-belligerent States by radioactive contamination but would involve the death of thousands, if not millions, of the inhabitants of territories not parties to the conflict. This would violate the principle of sovereign equality, enshrined in Article 2(1) of the UN Charter, an aspect that would appear not to have been taken fully into consideration by the Court when making its findings". ${ }^{33}$ The other 4 (four) judges who had dissented in their opinion had done so for various reasons as elaborated in their own dissenting opinions but were not specifically against the idea of prohibition of the threat or use of nuclear weapons even in extreme circumstances.

The author's concern in regards to the opinion is the unclear statement on the conclusion (2) e of the operative part. It is excellent that the Court acknowledged the inhumane characteristic of nuclear weapons, however, it is difficult to comprehend the limit of the Court's statement that "it would generally be contrary to the rules of international law". There is no sufficient explanation to justify the little

31 The Nuclear Advisory Opinion, Dissenting Opinion of Judge Weeramantry, p. 433.

32 The Nuclear Advisory Opinion, Dissenting Opinion of Judge Shahabuddeen, p. 428.

33 The Nuclear Advisory Opinion, Dissenting Opinion of Judge Koroma, p. 576. 
exception on this point, meanwhile, it is evident that utilizing nuclear weapons equals unnecessary suffering which will infringe the equality principle. The court throughout the proceedings never really explored the idea of the exceptions that will possibly permit employing a weapon with disproportionate destructive force.

The Opinion later in the statement suggested that if "an extreme circumstance of self-defence, in which the very survival of a State would be at stake" then it might become the possible exception to use nuclear weapons. However, there is no justification for the use of force under the quise of "self-defense" according to the existing laws. As a consequence, this part of the Court's Opinion would raise doubts regarding the efficacy of the non-proliferation regime developed within the United Nations, regenerating the legitimacy of claims to use nuclear weapons for exclusive national objectives. ${ }^{34}$ It will hinder the community's attempt that advocates for non-proliferation - not to mention, prohibition - of nuclear weapons in the very first place. ${ }^{35}$ It is also clear that the Court's approach to this matter centralizes the statesecurity, rather than focusing on the catastrophic impacts to humankind. Only the three judges who dissented saw the matter from a more humanitarian perspective.

Both of the cases that this article has delineated acknowledge the inhumane effect that nuclear weapons possess but even after a 30 years gap, the court failed to directly affirm the legality or illegality of it. The Shimoda case beautifully rendered its judgment based on fundamental principles in the law of war and the rule to prohibit weapons with unprecedented effects that cause unnecessary suffering despite the limitation of the existing rules. Meanwhile, the Court's Opinion has its loophole in regards to self-defence that was based on the doctrine of nuclear deterrence. It is important, however, to disregard the nuclear deterrence doctrine to attain the complete illegality of nuclear weapons.

34 Daniel Thürer, "The Legality of the Threat or Use of Nuclear Weapons: The ICJ Advisory Opinion Reconsidered," Revista Da Faculdade de Direito Da Universidade Federal de Minas Gerais 61 (2012): 229, https://doi.org/10.12818/p.0304-2340.2012v61p213. 


\section{SHIFTING PARADIGM: STATE SECURITY TO HUMANITARIAN APPROACH}

There is no objection coming from individuals or entities on the fact that nuclear weapons can be regarded as the most hazardous and devastating weapons ever discovered. Paradoxically, some reckon these factors will deter enemies from attacking ${ }^{36}$, and even though far from universal, it is generally assumed that the principle of nuclear deterrence delivers stability, security, and peace to the one who possesses the weapons. ${ }^{37}$ Not to mention the political prestige and economic benefit coming from it. On the other hand, the opposing group argued that the major detriment caused by nuclear weapons (e.g. possibility of the error) is inevitable, as such, nuclear disarmament is needed.

Notwithstanding, the aforementioned nuclear disarmament campaign has endured insufficient partaking from the public because the destructive impacts can be viewed as "unsituated risk", where the risk is not foreseeable by most people daily, just like climate change. ${ }^{38}$ Even if there is awareness of the nuclear threat, considering the level of complexities surrounding the issue of nuclear disarmament, it has led the public and even the media to abandon the matter. ${ }^{39}$ This article argues that one of the primary reasons why the campaigners of prohibition of nuclear weapons change the approach on the matter is a form of effort to include participation from as many individuals or groups of people as possible. Particularly on this part of the article, the Author will try to unravel the approaches that served as the basis in

36 Sauer and Reveraert, "The Potential Stigmatizing Effect of the Treaty on the Prohibition of Nuclear Weapons," 3.

37 Kenneth Waltz, "The Spread of Nuclear Weapons: More May Be Better," The Adelphi Papers 21, no. 171 (1981): 1.

38 Ben Paxton, "2017 Saw 122 Countries-but None of the Nuclear-Weapons States-Support the Treaty for the Prohibition of Nuclear Weapons. Why Is Nuclear Disarmament so Difficult and What Should Be the next Steps for Those Aiming for Prohibition?*," Medicine, Conflict and Survival 35, no. 4 (2019): 337, https://doi.org/10.1080/13623699.2020.1719580; Mike Hulme, Why We Disagree about Climate Change: Understanding Controversy, Inaction, and Opportunity, (Cambridge: Cambridge University Press, 2009).

39 Paxton, 337. 
both NPT and TPNW, the weaknesses and/or significance of each treaty, and the reason behind the shifting of the paradigm.

NPT, since its enforcement in 1970, was indeed a major step and "cornerstone" in achieving the objectives of the elimination of all atomic weapons. In general, the state's obligations perpetuated in this treaty are as follows: first, the Nuclear-weapon State Party (hereinafter "NWSP") undertook not to assist or encourage Non-nuclear-weapon State (hereinafter "NNWS") to manufacture or acquire nuclear weapons, meanwhile, the non-nuclear-weapon State Party (hereinafter "NNWSP") obliged to refrain themselves from manufacturing and/or acquiring nuclear weapons. ${ }^{40}$ Second, to verify the compliance of the NNWSPs to the principle and provisions under the treaty, they accepted the enactment of safeguarding measures by the International Atomic Energy Agency (IAEA), including inspections and monitoring in correlation with all the nuclear weapons or materials held within their territory. ${ }^{41}$ Third, the treaty still allowed the state parties to develop research, production, and use of nuclear energy for peaceful purposes and they had to have the obligations to facilitate and the right to participate in the fullest possible exchange of materials, equipment, technology, and information needed regarding the peaceful uses of nuclear energy, ${ }^{42}$ Finally, the state parties of the treaty were also required to engage in "negotiations" concerning the eliminations of nuclear weapons and to pursue nuclear disarmament. ${ }^{43}$

Observing the provisions above, it is clear that this treaty has established a strong legal basis and norm against the spread of nuclear arms internationally. The state obligations stipulated under the NPT put more burden on the NNWSP, to not conduct anything suspicious and "threatening" with nuclear weapons with the exchange of facilitation and cooperation of peaceful uses of nuclear energy with the NWS. In the Author's perspective, the NNWSP's obligations are imbalanced with the obligations of the NWSP, which are not obliged to do anything, because it is not within the interest of any NWSP to "encourage" or "assist" any state to pursue nuclear weapons. It is generally accepted that NWSPs intend to maintain themselves as powerful states, so "encouraging" and "assisting" any state to possess

\footnotetext{
40 NPT, Article I-II.

41 NPT, Article III.

42 NPT, Article IV.

43 NPT, Article VI.
} 
nuclear weapons would not bring them any favour. Thus, the only "authentic" obligation of the NWSPs is to engage in negotiations concerning the elimination of nuclear weapons, which later in the Article it would be delineated that they also fail this obligation.

It has been noted that all provisions under the NPT and particularly the provision to pursue nuclear disarmament in the latter part of the obligations of the treaty utilize the traditional approach of disarmament, which is the state security approach. Patrick McCarthy, in a United Nations Institute for Disarmament Research (UNIDIR) anthology, explains 3 (three) characteristics of the traditional approach. First, it inclines in framing the matter of threats to states and thus emphasizes the need for state security. ${ }^{44}$ Second, the exclusivity of the negotiation process, which only includes the high-end officials and experts, such as diplomats, military experts, and some selected groups of scientific-technical experts. ${ }^{45}$ Third, traditional disarmament is generally 'bureaucratic, cumbersome, and time-consuming. ${ }^{, 46}$

These traits inflict a severe blow to achieving the objective of nuclear disarmament. The focus will only be centralized to the interest of the states in itself, thus NWS will forward any arguments relevant to their interest to dodge the idea of nuclear disarmament. Not to mention, its exclusive nature which compartmentalizes civil society organizations as "outsiders", whereas its existence is extremely important to achieve the goal. It is indeed true that the high-end officials and policymakers make the decisions, but the interference of civil society is the one that mobilizes and generates the political will for change. ${ }^{47}$ Consequently, criticism and pressure from the so-called "outsiders" will be underestimated by the policymakers and will be less relevant compared to the "interest" of the NWS, which regularly use

44 Patrick McCarthy, "Deconstructing Disarmament: The Challenge of Making the Disarmament and Arms Control Machinery Responsive to the Humanitarian Imperative," in , Alternative Approaches in Multilateral Decision Making: Disarmament as Humanitarian Action, ed. John Borrie and Vanessa Martin Randin (Geneva: UNIDIR, 2005), 51-66.

45 McCarthy, 56.

46 McCarthy, 56.

47 Paxton, "2017 Saw 122 Countries-but None of the Nuclear-Weapons States-Support the Treaty for the Prohibition of Nuclear Weapons. Why Is Nuclear Disarmament so Difficult and What Should Be the next Steps for Those Aiming for Prohibition?*," 2. 
the arguments that these weapons guarantee state security. The "nuclear deterrence" doctrine is problematic as it reinforces the narrative that possessing nuclear weapons will create higher levels of caution between states, and thus decreasing the possibility of conflict.

The successful practice of nuclear deterrence is highly contingent on the context of the threats; thus, it is uncertain and does not guarantee anything. For it to be successful, it requires the receiving party to believe that their opponent might utilize their nuclear power if the crisis continues to arise or escalates. ${ }^{48}$ Nick Ritchie in his brief stated that "there is no certainty of success if the deterree is determined to pursue its chosen course of action if it doesn't believe the nuclear deterrent threat to be credible...'. Furthermore, he also states that a successful nuclear deterrent threat is a process of convincing an adversary not to engage in a hostile course of action', which necessitates some knowledge regarding their motivation, worldview, resolve, and cost-benefit calculation. ${ }^{49}$

For instance, the Able Archer crisis could have almost been an example of the failure of the nuclear deterrence theory because of perception and paranoia. ${ }^{50}$ The year 1983 witnessed deteriorating relations between two superpower countries that both possessed nuclear weapons, which were the United States and the Soviet Union. ${ }^{51}$ Throughout the year, the two superpowers had deployed their nuclear weapons to each other, either by deed or word. This was intensified and had reached its peak in November when NATO held its annual command-post exercise, the Able Archer, that was designed to test and rehearse nuclear release procedures and somehow was identified as a particular focus of anxiety. ${ }^{52}$ The Soviet officials at the time were extremely concerned that this exercise might be a covert plan of the United States to launch a genuine nuclear attack. Fortunately, a preventive strike coming from the Soviet Union did not happen,

48 Nick Ritchie, "Nuclear Risk: The British Case," 2014, 2, http://www.article36.org/wp-content/uploads/2013/06/Nuclear-riskpaper.pdf.

49 Nick Ritchie, 3.

50 Nick Ritchie, 2.

51 Vojtech Mastny, “How Able Was 'Able Archer'?,” Journal of Cold War Studies 11, no. 1 (2009): 109.

52 Len Scott, "Intelligence and the Risk of Nuclear War: Able Archer-83 Revisited," Intelligence and National Security 26, no. 6 (2011): 759. 
because of the Soviet intelligence which identified US intentions correctly. ${ }^{53}$ However, the lessons learned from this phenomenon are summarized perfectly by the arguments of the CIA Director Robert Gates who stated that 'we were close to nuclear war without even knowing it. ${ }^{54}$ It is unfortunate that the acceptance of the deterrence doctrine has arguably undermined the influence of other considerations $^{55}$, and hampered nuclear disarmament.

Regardless of its controversy and critics, several studies have shown the effectiveness of the treaty on how the majority of states recognize the importance of being the NPT's contracting party, the functioning of the framework of the treaty as intended, and how the states parties decided to continue its existence. ${ }^{56}$ Concerning the latter part, the provision under Article 10 number 2 of the treaty stipulates that:

Twenty-five years after the entry into force of the Treaty, a conference shall be convened to decide whether the Treaty shall continue in force indefinitely or shall be extended for an additional fixed period or periods. This decision shall be taken by a majority of the Parties to the Treaty.

The above provision is indeed an unusual feature that differentiates NPT from most treaties under international law. The fact that this treaty still exists to date, means that the norms, rights, and obligations contained in the treaty are accepted and relevant to the majority of the states participating in the treaty. This stipulation also relates to another review-related provision under Article 8 number 3 which states that:

Five years after the entry into force of this Treaty, a conference of Parties to the Treaty shall be held in Geneva, Switzerland, in order to review the operation of this Treaty with a view to assuring that the purposes of the Preamble and the provisions of the Treaty are being realised. At intervals of five years thereafter, a majority of the Parties to the Treaty may obtain, by submitting a proposal to this

53 Dmitry Dima Adamsky, "The 1983 Nuclear Crisis - Lessons for Deterrence Theory and Practice," Journal of Strategic Studies 36, no. 1 (2013): 30 .

54 Adamsky, 31.

55 Minor, "Changing the Discourse on Nuclear Weapons: The Humanitarian Initiative," 713.

56 See: Manseok Lee, et.al., "Challenges to the Nuclear Non-Proliferation Treaty”, Strategic Studies Quarterly 14, no. 3 (2020): p. 95-120. 
effect to the Depositary Governments, the convening of further conferences with the same objective of reviewing the operation of the Treaty.

Collectively, both provisions consequently gathered the state parties from 17 April to 12 May 1995, to decide whether or not the treaty should be continued in force, for how long the treaty should be extended and simultaneously also reviewing the performance of the treaty for 1990 until 1995. There were 3 (three) decisions taken during this conference: First, the decision of "Strengthening the Review Process". Second, the decision of the "Principles and Objectives", which includes the 'determined pursuit' by the NWSP of 'systematic and progressive efforts' to 'reduce' nuclear weapons globally, with the 'ultimate goals' of nuclear disarmament and general and complete disarmament. ${ }^{57}$ Third, regarding The Indefinite Extension, it was said that by the time the Conference began on 17th April 1995, the majority of states had decided to vote for extending the Treaty indefinitely. ${ }^{58}$

However, over time, despite the result, frustrations had been expressed by the international community regarding the slow progress of the 1995 NPT Conference decisions, particularly on decision number two. Those who supported complete nuclear disarmament had accused NWSP of not being serious enough about nuclear disarmament. ${ }^{59}$ Even since the treaty's adoption, the progress towards the goals of complete nuclear disarmament mentioned under Article 6 of the treaty has been extremely limited at the multilateral level ${ }^{60}$ The accusation is also supported by the fact that twenty years after the 1995 Review Conferences, its implementation only alternated between manufacturing plans to attain total elimination of nuclear weapons and

57 Jayantha Dhanapala and Tariq Rauf, "Reflections on the Treaty on the Non-Proliferation on the Non-Proliferation," 2017, 51.

58 Dhanapala and Rauf, 12.

59 Rebecca Davis Gibbons, "The Humanitarian Turn in Nuclear Disarmament and the Treaty on the Prohibition of Nuclear Weapons," Nonproliferation Review 25, no. 1-2 (2018): 11, https://doi.org/10.1080/10736700.2018.1486960.

60 Daniel Rietiker, Humanization of Arms Control Paving the Way for a World Free of Nuclear Weapons (Routledge, 2019), 2. 
always ended up with failure to generate a consensus. Thus, it is deemed as "woefully inadequate". ${ }^{61}$

Following the failure of the 2005 NPT Review Conference, nongovernmental organizations (NGOs), some middle-power governments, foreign ministries, and UN officials together through formal and/or informal meetings tried to explore the ideas on how to accelerate the process of nuclear disarmament, in which the end outcome of the consensus was expected to be achieved by the end of the decade through the application of a more salient humanitarian approach. $^{62}$

Elizabeth Minor argued that the rise in humanitarian concerns into the international discussion between States was related to two key developments: ${ }^{63}$ First, the International Red Cross and Red Crescent Movement (hereinafter "the Movement") had been re-connected with the matter of nuclear arms from a humanitarian perspective since 2009. Furthermore, it was also supported by the public statements of the President of the International Committee of the Red Cross (hereinafter "ICRC"), Jakob Kellenberger, in April 2010 that laid out in a sharply striking framework concerning the unacceptable humanitarian consequences of nuclear weapons. He also urged critical action from States to cease the threat that nuclear weapons possess. Secondly, the Final Document of the 2010 Review Conference of the Parties to the NPT delineates that the utilization of nuclear weapons would result in catastrophic humanitarian consequences and the continued risk these weapons hold was noted as a matter of concern. President Obama's speech in Prague in 2009, surprisingly, also contributed to the reemergence of humanitarian perspectives, where he supported and endorsed the objectives of a world free of nuclear weapons. To be exact, President Obama's statement was as follows:

No nuclear war was fought between the United States and the Soviet Union, but generations lived with the knowledge that their world could be erased in a single flash of light. Cities like Prague that

61 Women's International League for Peace and Freedom (WILPF), 2017 NPT Briefing Book, April 2017, p. 8 (accessed 28 November 2020).

62 Gibbons, "The Humanitarian Turn in Nuclear Disarmament and the Treaty on the Prohibition of Nuclear Weapons," 5.

63 Minor, "Changing the Discourse on Nuclear Weapons: The Humanitarian Initiative," 713. 
existed for centuries, that embodied the beauty and the talent of so much of humanity, would have ceased to exist.

However, almost eight years after this speech, he conducted a $\$ 35$ billion programme to modernize the entire US nuclear arsenals for the next decades. ${ }^{64}$ At that time, the statement had assisted to establish a positive political context for the NPT Review Conference and recharging those working on nuclear disarmament at a diplomatic level.

The Oslo conference, attended by one hundred and twenty-two nations, also played a significant role in reframing the nuclear disarmament approach. Concluding the Conference, the Norwegian Government emphasized three main points ${ }^{65}$ : First, any entity possessing nuclear weapons is extremely unlikely - almost impossible - to address sufficiently the immediate humanitarian necessity right after a nuclear explosion. Second, nuclear weapons have devastating short and also long-term impacts. Third, the impacts of nuclear weapons will not only be experienced at a national or domestic level but will also affect the international community.

The participants of the conference conceded that the Oslo conference deviated from any other nuclear-related meeting they had attended before. ${ }^{66}$ It also should be noted that during this conference, the leaders of the International Campaign to Abolish Nuclear Weapons (ICAN) declared the need for a legally binding treaty as "the most effective guarantee" against nuclear weapons. ${ }^{67}$ Thereafter, humanitarian conferences were seen as a strategy to delegitimize nuclear weapons and to establish support for a nuclear ban.

In responding to the Conference, the five NWS of the NPT made a joint declaration which basically declared that they were at a unified decision not to participate in such a conference, and accused that the conference would "divert discussion away from practical steps" toward

64 Fred Kaplan, "Rethinking Nuclear Policy: Taking Stock of the Stockpile," Foreign Affairs 95, no. 5 (2016): 18.

65 Gibbons, "The Humanitarian Turn in Nuclear Disarmament and the Treaty on the Prohibition of Nuclear Weapons," 10.

66 Gibbons, 10.

67 Rebecca Johnson, "ICAN Intervention in Final Session of the Conference on the Humanitarian Impact of Nuclear Weapons," in Conference on the Humanitarian Impact of Nuclear Weapons (Oslo, 2013), 1-2. 
nuclear disarmament. ${ }^{68}$ They contended that the practical step-by-step approach under the implementation of three pillars of NPT disarmament, non-proliferation, and the peaceful uses of nuclear energy - has proven to be "the most effective means" to increase stability and reduce nuclear dangers. This paper contends that this accusation is a false pretext to justify their nuclear conduct and to avoid the attempt and pressure for them to disarm their nuclear programmes. To date, there has not been a vivid effort under the "practical steps" by NWS to aim for nuclear disarmament under NPT.

The increasing amount of attention and consideration on the catastrophic consequences of the utilization of nuclear weapons at the international level during that time also led to the UN General Assembly's decision to establish an open-ended working group (OEWG) in January 2013 to draft proposals in activating multilateral nuclear disarmament negotiations. ${ }^{69}$ Furthermore, taking place in Geneva, with a total of fifteen days in 2016, a second OEWG was held and the sessions were attended by 100 states and also the representatives of international organizations, NGOs, and academics, with the absence of all the NWS. This concluded in a resolution summoning UN member states to conduct negotiations in 2017 on banning nuclear weapons, which eventually generated TPNW. During the negotiations, it became apparent that a future treaty would take the shape of treaties such as the Ottawa and Oslo Conventions, which can be categorized as "ban" or "prohibition" treaties. ${ }^{70}$

To distinguish the humanitarian approach on nuclear disarmament and the traditional approach, Patrick McCarthy highlights three stark points of differences: ${ }^{71}$ First, there is a shifting of focus from centralizing on the security of the state to 'the security and well-being of people living within states'. Therefore, this will correlate to the notion of human security that was defined in 1994 by the UN

68 See: www.reachingcriticalwill.org/images/documents/Disarmamentfora/oslo-2013/P5_Oslo.pdf.

69 UNGA Resolution 65/56 (UN Doc. A/RES/67/5), 4 January 2013, Taking forward multilateral nuclear disarmament negotiations.

70 Daniel Rietiker, Humanization of Arms Control Paving the Way for a World Free of Nuclear Weapons, 331.

71 McCarthy, "Deconstructing Disarmament: The Challenge of Making the Disarmament and Arms Control Machinery Responsive to the Humanitarian Imperative," 56. 
Development Programme as synchronizing 'security with people rather than territories, with development rather than arms'. Second, unlike traditional approaches that are more exclusive, the process of negotiation on humanitarian approaches tends to be more transparent and inclusive rather than traditional approaches. The groups, especially civil society organizations, representing the interests of people who have been or could be harmed by certain weapons, play a significant role in identifying the issues and determining how to address them. This is in line with this paper's argument that it is important to be inclusive for all parties. Third, the focus on speed, innovation, and flexibility of the humanitarian approach results in strict deadlines.

The humanitarian approach in TPNW is very apparent. Among twenty-four paragraphs in the Preamble of the Treaty, there are approximately twelve paragraphs that highlight the concern on humanity and humanitarian issues. For example, this paper takes two paragraphs of the Preamble that mirror the overall objectives and processes in the making of the Treaty, which reads as follows:

Acknowledging the ethical imperatives for nuclear disarmament and the urgency of achieving and maintaining a nuclear-weapon-free world, which is a global public good of the highest order, serving both national and collective security interests,

Stressing the role of public conscience in the furthering of the principles of humanity as evidenced by the call for the total elimination of nuclear weapons, and recognizing the efforts to that end undertaken by the United Nations, the International Red Cross and Red Crescent Movement, other international and regional organizations, nongovernmental organizations, religious leaders, parliamentarians, academics, and the hibakusha,"

Though the Preamble does not contain legally binding obligations, it is a significant tool for the interpretation of the international agreement, particularly in defining its 'object and purposes' ${ }^{72}$ This is in accordance with Article 31 of the Vienna Convention on the Law of the Treaties, which stipulates that a "treaty

72 Daniel Rietiker, "The Treaty on the Prohibition of Nuclear Weapons: A Further Confirmation of the Human and Victim-Centred Trend in Arms Control Law," in Nuclear Non-Proliferation in International Law Volume IV, ed. Jonathan L Black-branch and Dieter Fleck (TMC Asser Press, 2019), 332. 
shall be interpreted in good faith in accordance with the ordinary meaning to be given to the terms of the treaty in their context and in the light of its object and purpose." From the aforementioned Preamble, it is argued that the elimination of nuclear weapons is objective and is in the interest of all States. ${ }^{73}$

In relation to the above, the TPNW drafters considered that the legal norms and obligations instilled in the Treaty are "common interest to humanity" and therefore, erga omnes in nature. ${ }^{74}$ Erga omnes obligations are those international customary obligations that are the concern of every state since they are owed towards the international community as a whole, rather than towards one or more states. ${ }^{75}$ This is interesting, because the TPNW drafters claim that the TPNW obligations are "customary", and therefore contradicts to Court's Opinion, as explained in the previous part of the article, for the Court did not find any "opinio juris" to complete the prerequisite for the obligations of TPNW to be categorized as "customary".

Deviating from its predecessors, the TPNW Preamble combines humanitarian and state security approaches, which can be seen in the provisions such as "... serving both national and collective security interests". Moreover, the humanitarian approach is also manifested in the provision of victim assistance and environmental remediation under Article 6 of the Treaty. The provisions read as follows:

1. Each State Party shall, with respect to individuals under its jurisdiction who are affected by the use or testing of nuclear weapons, in accordance with applicable international humanitarian and human rights law, adequately provide age- and gender-sensitive assistance, without discrimination, including medical care, rehabilitation, and psychological support, as well as provide for their social and economic inclusion.

2. Each State Party, with respect to areas under its jurisdiction or control contaminated as a result of activities related to the testing or use of nuclear weapons or other nuclear explosive devices,

73 Daniel Rietiker, 334.

74 Daniel Rietiker, 334.

75 Marco Longobardo, "The Contribution of International Humanitarian Law to the Development of the Law of International Responsibility Regarding Obligations Erga Omnes and Erga Omnes Partes," Journal of Conflict and Security Law 23, no. 3 (2018): 385. 
shall take necessary and appropriate measures towards the environmental remediation of areas so contaminated.

3. The obligations under paragraphs 1 and 2 above shall be without prejudice to the duties and obligations of any other States under international law or bilateral agreements.

From all the explanations above, we can conclude that the reason behind the shifting of paradigm in the nuclear weapons-related treaty was the disinterest in the traditional approach. The exclusivity character of the state-centered approach will not bring any improvement to the end goal of NPT, which is complete disarmament. It will be much harder for the public to partake in the nuclear arms discourse, because of the technically heavy discussion which is hard to be comprehended by an average reasonable person. These characteristics are stark in contrast with the new humanitarian approach that emphasizes how nuclear weapons are too disastrous to be utilized and how they will create catastrophic impacts that no country could be capable of managing, which is more digestible for the public. The inclusivity and the increasing public participation from the humanitarian approach are evident from the establishment process of the Treaty, where the stimulation came from the civil society organization, whose voices were ignored during the traditional approach. This paper argues that the existence of public participation is crucial for pressuring and putting a burden on the NWS to dismantle their weapons which previously could easily be washed off by the "state-interest" argument by the policymakers.

\section{OBSTACLES}

In the previous part, we have unraveled the shifting paradigm of the discourse concerning nuclear weapons in the international sphere. The humanitarian approach has successfully created a nuclear weapon ban treaty; however, the succeeding question is, will it lead to a truly complete nuclear disarmament? What are the possible obstacles that this Treaty will encounter? There are already some critics from the NWS saying that the TPNW supporters are frivolous about 
disarmament because of the lack of crucial details in some of the contained provisions ${ }^{76}$ which will be elaborated on later.

First of all, it has been known that universality is the key to complete nuclear disarmament. How could we achieve a world without nuclear weapons, when the most important actors do not want to participate in the movement? This is one of the primary problems of the Treaty, where among 122 signatories, there are no participants from the NWS convincing all nine nuclear weapons states, including North Korea, to ratify and be a contracting party to this Treaty seems very unlikely - almost impossible- for them to join in the foreseeable future. ${ }^{77}$ Not to mention that some nuclear-armed states even boycotted the negotiations and the fact that North Korea had withdrawn itself from NPT and never showed intention to cooperate in any humanitarian movement. This, of course, brings a skeptical view towards the Treaty, seeing it as ineffective and will not make any difference. While that may be true in the short and medium-term, it is argued that in the long term, through political or any other form of pressure coming from the NWS allies (e.g. Norway), it may bring significant impact to the table. ${ }^{78}$

The idea of the humanitarian paradigm on the Treaty is that they will go through a step-by-step approach to the NWS. The initial step would be convincing a nuclear weapon state that is more approachable and more likely to be convinced than others, for example, the UK.$^{79}$ If the UK capitulates, there will be a domino effect towards other NWS to also capitulate especially those who only possess it for reasons of prestige. ${ }^{80}$ Nonetheless, until the idealized theory is applied and proven, the doubts toward this Treaty are justified and legitimate.

76 Heather Williams, "A Nuclear Babel: Narratives around the Treaty on the Prohibition of Nuclear Weapons," Nonproliferation Review 25, no. 1-2 (2018): 51, https://doi.org/10.1080/10736700.2018.1477453.

77 Docherty, “A 'Light for All Humanity': The Treaty on the Prohibition of Nuclear Weapons and the Progress of Humanitarian Disarmament," 18.

78 Tom Sauer and Joelien Pretorius, "Nuclear Weapons and the Humanitarian Approach," Global Change, Peace and Security 26, no. 3 (2014): 248.

79 Sauer and Pretorius, 249.

80 Barry O’Neill, "Nuclear Weapons and National Prestige," Cowles Foundation Discussion Paper No. 1560 (Los Angeles, 2006), 4. 
Secondly, there are also concerns about how the existence of TPNW will reduce the significance and obligations under NPT which is a nuclear weapon-related treaty with the biggest participation rate, with only India, Israel, North Korea, Pakistan, and South Sudan as nonparties. TPNW rules that their existence will not diminish other obligations from other treaties. Articles 18 of the Treaty stipulates that:

The implementation of this Treaty shall not prejudice obligations undertaken by States Parties with regard to existing international agreements, to which they are party, where those obligations are consistent with the Treaty.

Paragraph 18 also reaffirms the "full and effective implementation" of the NPT. However, it should be noted that the latter part of the provisions under Article 18 states that the obligations under any international nuclear-related treaty (i.e. NPT) will continue to exist as long as they are in line with the provisions under the TPNW. Thus, it will put NPT (or another nuclear-related treaty) under TPNW in some kind of "hierarchical" order rather than being interpreted and implemented as "complementing". The logical basis of this rule allegedly comes from the legal principle "lex posteriori derogat legi inferiori", which means when one provision under a legal instrument contradicts with another provision under a newer legal instrument, then the one that prevails is the provision under the newer legal instrument. This rule is consistent with criticisms of the NPT from TPNW supporters.

Highsmith gives an example to portray the confusion, for instance, if a state party to TPNW might allege that cooperation of nuclear weapon for peaceful purposes (a primary foundation of NPT) with an NWS. This would violate the "assist, encourage, or induce" prohibition in Article 1 (e) of TPNW. ${ }^{81}$ However, it can be argued that this portrayal has been blown out of proportion, because the provision under Article 1 (e) clearly states that the obligation not to "assist, encourage, or induce" is intended for activities that are prohibited under the Treaty. Meanwhile, there is no prohibition of peaceful cooperation under TPNW. Even more, in paragraph 21, the Preamble of the Treaty prescribes that:

81 Newell Highsmith and Mallory Stewart, "The Nuclear Ban Treaty: A Legal Analysis," Survival 60, no. 1 (2018): 141, https://doi.org/10.1080/00396338.2018.1427371. 
Emphasizing that nothing in this Treaty shall be interpreted as affecting the inalienable right of its States Parties to develop research, production and use of nuclear energy for peaceful purposes without discrimination,

It is observed that TPNW in principle supports all the state obligations ruled under NPT. However, it is established that the practice of the "negotiations" provision for nuclear disarmament had remained stagnant, not because of the lacking of the fulfilment of state obligations provisions. Yet, this paper agrees that there may be potential difficulties felt by the state parties of both treaties in deciphering the legal application of one regime to another, as there may be some provisions of the TPNW that are hard to differentiate from the NPT. ${ }^{82}$

Another significant problem within the Treaty, which is also the primary accusation by the NWS, is regarding the non-comprehensive provision on the verification process. Article 4 assigns the task of verification to "competent international authority or authorities" designated by the state parties, and where the designation has not been made, it is allegedly and highly likely that the burden will be put to the International Atomic Energy Agency (IAEA). ${ }^{83}$ Under that assumption, while it is already proven in the South Africa case that IAEA is capable of doing verification, several questions remain unanswered, such as how to integrate the additional specific task of IAEA to the constitutive documents of IAEA itself as well as how to finance its activities. ${ }^{84}$

Moreover, for the verification provisions to be effective, TPNW needs to address it by being more invasive and much more demanding than under NPT. It will require a more comprehensive set of indicators for a programme, as well as capabilities for monitoring those indicators. ${ }^{85}$ It should also extend to the existing stock of fissile

82 See: Carlo Trezza, "The UN Nuclear Ban Treaty and the NPT: Challenges for Nuclear Disarmament," Istituto Affari Internazionali Commentaries 17, no. 15 (2017): 1-3.

83 Fleck, "The Treaty on the Prohibition of Nuclear Weapons: Challenges for International Law and Security," 405.

84 Fleck, 405.

85 Tamara Patton, “An International Monitoring System for Verification to Support Both the Treaty on the Prohibition of Nuclear Weapons and the 
material; to enrichment and reprocessing facilities; to naval reactors that use highly enriched materials, etc. ${ }^{86}$ To answer the verification obstacles, Tamara Patton proposes for the establishment of a new twopart organizational structure, consisting of an Implementation Support Unit (ISU) and a Scientific and Technical Advisory Board (SAB), which is obliged to support the implementation of the Treaty and further advances the development and manifestation of its disarmament verification provisions. ${ }^{87}$ Furthermore, the non-existence of specific safeguards obligations for NNWS may also become a problem in the case of tacit development of acquisition. ${ }^{88}$

\section{Conclusion}

The discourse on the legitimacy of threats and the use of nuclear weapons has been going around for decades. ICJ's Advisory Opinion did not play a part in assisting the delegitimization of nuclear weapons, it even to some extent emboldened the utilization of nuclear weapons for the protection of a country. The traditional approach of nuclear disarmament that the NPT employs is of no help at all, where it centralizes the focus of disarmament to the interests of the state. This approach is easily contended by the "nuclear deterrence" principle, where the existence of nuclear weapons is seen as crucial as it can provide security, maintain peace, and prevent conflicts to escalate. The humanitarian approach emerged as the catalyst to achieve a world without nuclear weapons rendered by the disappointment of the stagnant NPT progress. The inclusive characteristic is also one of the primary reasons behind the successful negotiation of the TPNW's treaty-making process.

However, the efforts of nuclear disarmament and humanitarian advocates should not stop even after the implementation of TPNW. The

Nonproliferation Treaty," Global Change, Peace and Security 30, no. 2 (2018): 20, https://doi.org/10.1080/14781158.2018.1467392.

86 Fleck, "The Treaty on the Prohibition of Nuclear Weapons: Challenges for International Law and Security," 405-6.

87 Patton, Philippe, and Mian, "Fit for Purpose: An Evolutionary Strategy for the Implementation and Verification of the Treaty on the Prohibition of Nuclear Weapons," 3.

88 Fleck, "The Treaty on the Prohibition of Nuclear Weapons: Challenges for International Law and Security," 407. 
primary objective of the existence of TPNW is to eradicate nuclear weapons, so certainly the most important stakeholders to achieve this aim are the nuclear weapons states. Changing the stance of the nuclear weapons state, convincing them to be state parties of TPNW, and thus dismantling their nuclear arms will be extremely strenuous. Until the "domino effect" theory that is propagated by the proponents of TPNW is proven, the skepticism towards this Treaty is justified. Regardless of the obstacles and the extreme difficulty that the Treaty will encounter, it should be noted that the establishment of TPNW itself is a tremendous achievement considering the stagnation of the state security approach. The thing is, if it is not the prohibition treaty, then what would be the alternative to accelerate nuclear disarmament? Should the international society just tacitly accept and trust the NWS to control their arsenals "responsibly", with the lives of millions at stake? 